\title{
Control of threadleaf rubber rabbitbrush with herbicides
}

\author{
STEVEN G. WHISENANT
}

\section{Abstract}

Foliar sprays of 2,4-D [(2,4-dichlorophenoxy)acetic acid], picloram (4-amino-3,5,6-trichloro-2-pyridinecarboxylic acid), dicamba (3,6-dichloro-2-methoxy benzoic acid), or clopyralid (3,6-dichloro-2pyridinecarboxylic acid) were applied in 30 or $150 \mathrm{~L}$ of total spray solution ha-1 to threadleaf rubber rabbitbrush [Chrysothamnus nauseosus ssp. consimilis (Greene) Hall \& Clem] in Garfield County, Utah. Additional herbicide treatments were applied in 150 $L$ ha-1 $^{-1}$ in Sevier County, Utah. Herbicides were less effective when applied in $30 \mathrm{~L} \mathrm{ha-1}$ than when applied in $150 \mathrm{~L}$ of total spray solution ha-1. Mortality was 74 to $87 \%$ following applications of $4.4 \mathrm{~kg}$ a.e. (acid equivalent) 2,4-D ha-1. Dicamba applied at $3.3 \mathrm{~kg}$ $\mathrm{ha}^{-1}$ resulted in 70 to $87 \%$ mortality, and picloram applied at $0.8 \mathrm{~kg}$ ha.1 resulted in 56 to $79 \%$ mortality. The greatest mortalities (84 to 97\%) occurred on areas treated with $2.2 \mathrm{~kg}$ clopyralid ha-1. Mortality of threadleaf rubber rabbitbrush increased an average of 28,17 , 33 , and $27 \%$ following applications of $2,4-D$, dicamba, picloram, and clopyralid respectively, by using $150 \mathrm{~L}$ spray volume. Greatest increases were at the lowest herbicide rates. Applying herbicides in greater amounts of carrier (water) significantly increased both mortality and canopy reduction of threadleaf rubber rabbitbrush for at least 39 months.

Key Words: clopyralld, dicamba, picloram, 2,4D, spray volume

At least 8 species of rabbitbrush (Chrysothamnus spp.) occur in the Great Basin area of the western United States. They are most abundant on open plains, valleys, foothills, and mountains to 3,300 m (Hitchcock et al. 1969). Rabbitbrush frequently increases following removal of big sagebrush (Artemisia tridentata Nutt.) with fire, heavy grazing, or herbicides. Most herbicide applications for rabbitbrush contol have been directed at rubber rabbitbrush [Chrysothamnus nauseosus (Pallas) Britt.] or green rabbitbrush [Chrysothamnus viscidiflorus (Hook.) Nutt.].

Rubber rabbitbrush is most susceptible to conventional herbicides when new leader growth reaches 6 to $9 \mathrm{~cm}$ (Hyder et al. 1958, Mohan 1973, Cluff et al. 1983) and is less susceptible in dry years. Mohan (1973) suggested spraying rubber rabbitbrush with $2.2 \mathrm{~kg}$ 2,4-D [(2,4-dichlorophenoxy) acetic acid $]$ ester ha $^{-1}$ only when new leader growth exceeded $10 \mathrm{~cm}$ and enough water is present in the upper $10 \mathrm{~cm}$ of soil for rapid growth of rubber rabbitbrush.

Cluff et al. (1983) evaluated the efficacy of picloram (4-amino3,5,6-trichloro-2-pyridinecarboxylic acid), dicamba (3,6-dichloro2-methoxybenzoic acid), silvex [2-(2,4,5-trichloro-phenoxy)propionic acid], 2,4,5-T [(2,4,5-trichlorophenoxy) acetic acid], and triclopyr $\{[(3,5,6$-trichloro-2-pyridinyl)oxy]acetic acid $\}$ on threadleaf rubber rabbitbrush [Chrysothamnus nauseosus ssp. consimilis (Pallas) Britt.] in central Nevada. They reported threadleaf rubber rabbitbrush mortalities averaged $87 \%$ on areas sprayed with $2.2 \mathrm{~kg}$ 2,4-D ha ${ }^{-1}$. Mortality following applications of triclopyr $(3.4 \mathrm{~kg}$ $\left.\mathrm{ha}^{-1}\right)$, silvex $\left(3.4 \mathrm{~kg} \mathrm{ha}^{-1}\right)$, or dicamba $\left(3.4 \mathrm{~kg} \mathrm{ha}^{-1}\right)$ were similar to 2,4-D.

Despite data indicating adequate control of rubber rabbitbrush with available herbicides, many resource managers report poor results. Newer herbicides and/or different application techniques may increase efficacy of rubber rabbitbrush control efforts. Objec-

\footnotetext{
The author is associate professor, Dept. of Range Science, Texas A\&M University, College Station, Texas 77843-2126.

This research was conducted while the author was on the Botany and Range Science Faculty at Brigham Young University.

Manuscript accepted 29 June 1988.
}

tives of this study were to (1) compare threadleaf rubber rabbitbrush control achieved with clopyralid (3,6-dichloro-2-pyridinecarboxylic acid) versus control achieved with previously recommended herbicides and (2) to evaluate the influence of spray volume on herbicide efficacy.

\section{Materials and Methods}

\section{Study Sites}

Experiments were established near Antimony (Garfield County) and Salina (Sevier County), Utah. The Garfield County site was dominated by mountain big sagebrush [Artemisia tridentata ssp. vaseyana (Rydb.) Beetle] and threadleaf rubber rabbitbrush at $2,290 \mathrm{~m}$ elevation with a mean annual precipitation of $36 \mathrm{~cm}$. About $50 \%$ of the precipitation falls during the 90 -day growing season. Soil at this site was a Codley silt loam (fine, silty, carbonatic, frigid Ustic Torriorthent).

The Sevier County site was dominated by threadleaf rubber rabbitbrush growing on silty loams (fine, silty, mixed, frigid Xerollic Haplargid). This site is at 1,919 m elevation with a mean annual precipitation of $37 \mathrm{~cm}$. About $80 \%$ of the annual precipitation falls between November and April. The mean frost-free period is about 100 days.

\section{Herbicide Applications}

Herbicide treatments at both sites were applied to 3 replications of 3- by $30-\mathrm{m}$ plots in randomized complete block designs. Herbicides were applied in water with a $\mathrm{CO}_{2}$-powered backpack sprayer in 30 or $150 \mathrm{~L}$ total spray solution ha ${ }^{-1}$ at the Garfield County site and at $150 \mathrm{~L} \mathrm{ha}^{-1}$ at the Seiver County site. Application rates for each herbicide were based on previous research; however, because clopyralid had not been reported previously, a wider range of rates $\left(0.6\right.$ to $2.2 \mathrm{~kg} \mathrm{ha}^{-1}$ ) was used. A commercial surfactant (a mixture of alkyl-polyoxyethylene glycols, free fatty acids, and isopropanol) was included at $0.5 \%(\mathrm{v} / \mathrm{v})$.

Treatments at the Garfield County site were applied on 20 July 1983 and 16 June 1984. Treatments were the propylene glycol butyl ether ester of $2.4-\mathrm{D}$ at 2.2 and $4.4 \mathrm{~kg}$ a.e. $\mathrm{ha}^{-1}$; the dimethylamine salt of dicamba at 3.3 and $4.4 \mathrm{~kg}$ a.e. $\mathrm{ha}^{-1}$; the potassium salt of picloram at 0.6 and $0.8 \mathrm{~kg}$ a.e. $\mathrm{ha}^{-\mathrm{P}}$ and; the monoethanolamine salt of clopyralid at $0.6,1.1$, and $2.2 \mathrm{~kg}^{\mathrm{a} . e .} \mathrm{ha}^{-1}$. New leader growth of threadleaf rubber rabbitbrush was 5 to $12 \mathrm{~cm}$ during both the 1983 and 1984 applications. Air temperature was 19 to $23^{\circ} \mathrm{C}$ and relative humidity was 39 to $47 \%$ during the 1983 applications. Temperature and relative humidity were 18 to $24^{\circ} \mathrm{C}$ and 48 to $54 \%$ respectively, during the 1984 applications. Soil-water content was not measured, but the associated herbaceous vegetation was actively growing during both the 1983 and 1984 applications.

Treatments were applied at the Sevier County site on 14 June 1984. Dicamba ( $\left.3.3 \mathrm{~kg} \mathrm{ha}^{-1}\right)$, clopyralid (1.1 and $\left.2.2 \mathrm{~kg} \mathrm{ha}^{-1}\right)$, and 2,4-D (3.3 and $\left.4.4 \mathrm{~kg} \mathrm{ha}^{-1}\right)$ were applied in $150 \mathrm{~L}$ of total spray solution ha ${ }^{-1}$. Ambient temperature was 17 to $25^{\circ} \mathrm{C}$, relative humidity was 28 to $40 \%$, and threadleaf rubber rabbitbrush leader growth was 4 to $8 \mathrm{~cm}$ when herbicides were applied. Associated herbaceous vegetation was still green when herbicides were applied, but grass leaves were beginning to fold from water-stress.

\section{Evaluations}

Treatments were evaluated in Oct. 1985 and Oct. 1986. The 1986 evaluations followed third and fourth post-treatment growing seasons of the 1984 and 1983 applications, respectively. No significant 
differences were found between Oct. 1985 and Oct. 1986 evaluations of plots treated in 1983. Consequently, Oct. 1986 evaluations were used as the final evaluation on experiments initiated in 1983 and 1984.

Percentage canopy reduction (CR) of each woody plant rooted within a $25-\mathrm{m}$ long by $2-\mathrm{m}$ wide belt transect in each plot was visually estimated. Totally defoliated plants were examined for presence of basal or stem sprouts. The proportion of completely defoliated plants with no sprouts to the total number of plants was used as an estimate of mortality.

\section{Statistical Analysis}

Data were subjected to arc $\sin \sqrt{ } \mathrm{x}$ transformation prior to analysis of variance. The herbicide treatment by spray volume interaction was significant at the Garfield County site for both mortality and $C R$. Neither the application date by spray volume nor the application date by herbicide treatment interaction was significant at the Garfield County site. Analysis of variance was pooled over application dates for the Garfield County site and presented by treatment for each site. Least significant difference (L.S.D.) at the $5 \%$ level was used to separate statistically different treatment means.

\section{Results and Discussion}

Threadleaf rubber rabbitbrush mortality for the $150 \mathrm{~L} \mathrm{ha}^{-1}$ treatments was similar to those reported by Cluff et al. (1983) for

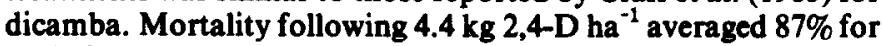
both sites when the higher spray volume was used and $74 \%$ with the lower spray volume. Shrub mortality exceeded $90 \%$ at the Garfield County site on areas sprayed with $4.4 \mathrm{~kg}$ dicamba ha ${ }^{-1}$ or 1.1 to 2.2 $\mathrm{kg}$ clopyralid ha ${ }^{-1}$ at $150 \mathrm{~L} \mathrm{ha}^{-1}$ spray volume (Table 1). No treatment produced over $88 \%$ mortality at the Sevier County site (Table 2).

Threadleaf rubber rabbitbrush mortality increased an average of $28,17,33$, and $27 \%$ following $2,4-\mathrm{D}$, dicamba, picloram, and clopyralid applications respectively, by using the higher total spray volumes. Those increases were always greatest at the lowest herbicide rates. Applying herbicides in greater amounts of carrier

Table 1. Canopy reduction $(\%)$ and mortality $(\%)$ of threadleaf rubber rabbitbruah following herbicide applications in Garfield County, Utah.

\begin{tabular}{|c|c|c|c|}
\hline \multicolumn{2}{|c|}{ Treatment } & \multirow[b]{2}{*}{$\begin{array}{c}\text { Canopy } \\
\text { reduction }(\%)\end{array}$} & \multirow[b]{2}{*}{$\begin{array}{c}\text { Mortality } \\
(\%)\end{array}$} \\
\hline Herbicide & $\begin{array}{c}\text { Rate } \\
\left(\mathrm{kg} \mathrm{ae} \mathrm{ha}^{-1}\right)\end{array}$ & & \\
\hline $\begin{array}{l}\text { None } \\
\text { 2,4-D } \\
\text { 2,4-D } \\
\text { Dicamba } \\
\text { Dicamba } \\
\text { Picloram } \\
\text { Picloram } \\
\text { Clopyralid } \\
\text { Clopyralid } \\
\text { Clopyralid }\end{array}$ & $\begin{array}{l}2.2 \\
4.4 \\
3.3 \\
4.4 \\
0.6 \\
0.8 \\
0.6 \\
1.1 \\
2.2\end{array}$ & $\begin{array}{c}-30 \mathrm{~L} \mathrm{ha}^{-1} \text { tot } \\
3 \\
52 \\
80 \\
84 \\
89 \\
39 \\
72 \\
41 \\
86 \\
91\end{array}$ & $\begin{array}{c}\text { ray volume-- } \\
0 \\
40 \\
74 \\
70 \\
81 \\
32 \\
56 \\
26 \\
81 \\
84\end{array}$ \\
\hline $\begin{array}{l}\text { None } \\
2,4-D \\
\text { 2,4-D } \\
\text { Dicamba } \\
\text { Dicamba } \\
\text { Picloram } \\
\text { Picloram } \\
\text { Clopyralid } \\
\text { Clopyralid } \\
\text { Clopyralid } \\
\text { L.S.D. }(0.05)\end{array}$ & $\begin{array}{l}-2.2 \\
4.4 \\
3.3 \\
4.4 \\
0.6 \\
0.8 \\
0.6 \\
1.1 \\
2.2\end{array}$ & $\begin{array}{c}-150 \mathrm{~L} \mathrm{ha}^{-1} \text { to } \\
5 \\
70 \\
93 \\
90 \\
97 \\
61 \\
88 \\
66 \\
96 \\
99 \\
6\end{array}$ & $\begin{array}{c}\text { pray volume-- } \\
1 \\
57 \\
87 \\
87 \\
95 \\
52 \\
79 \\
57 \\
95 \\
97 \\
7\end{array}$ \\
\hline
\end{tabular}

Table 2. Percentage canopy reduction and mortality of threadleaf rubber rabbitbrush following berbieide applieations in Sevier County, Utah.

\begin{tabular}{cccc}
\hline \hline & Treatment & & \\
Herbicide & $\begin{array}{c}\text { Rate } \\
\left(\mathbf{k g} \text { ae ha }{ }^{-1}\right)\end{array}$ & $\begin{array}{c}\text { Canopy } \\
\text { reduction (\%) }\end{array}$ & $\begin{array}{c}\text { Mortality } \\
(\%)\end{array}$ \\
\hline None & - & 4 & 0 \\
2,4-D & 3.3 & 90 & 85 \\
2,4-D & 4.4 & 91 & 87 \\
Dicamba & 3.3 & 84 & 77 \\
Picloram & 0.6 & 50 & 37 \\
Picloram & 0.8 & 78 & 69 \\
Clopyralid & 1.1 & 81 & 70 \\
Clopyralid & 2.2 & 93 & 88 \\
& L.S.D. (0.05) & 12 & 15 \\
\hline
\end{tabular}

(water) significantly increased both mortality and canopy reduction of threadleaf rubber rabbitbrush for at least 39 months. These data suggest that improved efficacy is possible with higher spray volumes. Improved efficacy with higher carrier volumes is probably due to improved coverage of herbicide on both the shrub canopies and leaf surfaces; possibly resulting in increased absorption.

Rubber rabbitbrush leaf surfaces are densely tomentose which minimizes contact of spray droplets with the leaf surface. For example, turkey mullein [Eremocarpus setigerus (Hook.) Benth.] plants were sprayed with 20 to $780 \mathrm{~L} \mathrm{ha}^{-1}$ total spray volume and the leaves examined with the cathodoluminescence detection mode of a scanning electron microscope (Hess et al. 1974). The amount of herbicide reaching the cuticle surface increased with increasing spray volumes (Hess et al. 1974). Similar results may be expected on rubber rabbitbrush when low spray-volumes are used.

Threadleaf rubber rabbitbrush mortality and CR were lower at the Sevier County site than the Garfield County site for all herbicides tested in $150 \mathrm{~L} \mathrm{ha}^{-1}$ total spray volume (Tables 1 and 2). Differing responses to herbicides may have been related to the winter precipitation regime of the Sevier County site compared to the Garfield County site, which receives more summer precipitation. By the time leader growth was sufficent for spraying at the Sevier County site, soil water contents appeared to have been low; resulting in less effective threadleaf rubber rabbitbrush control.

Picloram applied at $0.6 \mathrm{~kg} \mathrm{ha}^{-1}$ killed 32 to $52 \%$ of the threadleaf rubber rabbitbrush (Tables 1 and 2) but appeared to provide inconsistent control of big sagebrush (data not shown). These observations and the data of Tueller and Evans (1969) and Whisenant (1987) suggest that low rates $\left(0.3\right.$ to $\left.0.6 \mathrm{~kg} \mathrm{ha}^{-1}\right)$ of picloram may be used to control rubber rabbitbrush without eliminating big sagebrush.

The Siever County site also contained fourwing saltbush [Atriplex canescens (Pursh) Nutt.] in at least 1 replication of each treatment. All herbicides except clopyralid killed fourwing saltbush. Fourwing saltbush was also resistant to clopyralid in a west Texas study (Jacoby et al. 1981). Clopyralid has been shown to be highly selective between certain plant families in other studies (Bovey and Meyer 1981, OSullivan and Kossatz 1982, Whisenant 1987). Clopyralid also effectively controls big sagebrush without causing significant damage to such important shrub species as antelope bitterbrush [Purshia tridentata (Pursh.) DC.] or Saskatoon serviceberry (Amelanchier alnifolia Nutt.)(Whisenant 1987). This potential for increasing the selectivity of rangeland herbicide applications should be examined in other communities.

These data suggest that threadleaf rubber rabbitbrush can be effectively controlled $(\geq 87 \%$ mortality) with sprays of clopyralid at $2.2 \mathrm{~kg} \mathrm{ha}^{-1}$, dicamba at $4.4 \mathrm{~kg} \mathrm{ha}^{-1}$, or $2,4-\mathrm{D}$ ester at $4.4 \mathrm{~kg} \mathrm{ha}^{-1}$ applied in spray volumes of $150 \mathrm{~L} \mathrm{ha}^{-1}$. Spray volumes of $30 \mathrm{~L} \mathrm{ha}^{-1}$ will decrease the efficacy of those herbicides. In a winterprecipitation regime, soil-water may be largely depleted before new leader growth reaches the recommended $10 \mathrm{~cm}$ length. Threadleaf rubber rabbitbrush mortality may be reduced under those conditions. 


\section{Literature Cited}

Bovey, R.W., and R.E. Meyer. 1981. Effects of 2,4,5-T, triclopyr, and 3,6 dichloropicolinic acid on crop seedlings. Weed Sci. 29:256-261.

Cluff, G.J., B.A. Roundy, R.A. Evans, and J.A. Young. 1983. Herbicidal control of greasewood (Sarcobatus vermiculatus) and salt rabbitbrush (Chrysothamnus nauseosus ssp. consimilis). Weed Sci. 31:275-279.

Hess, F.D., D.E. Bayer, and R.H. Falk. 1974. Herbicidal dispersal patterns: I. As a function of leaf surface. Weed Sci. 23:394-401.

Hitchcock, C.L., A. Cronquist, M. Ownbey, and J.W. Thompson. 1969. Vascular plants of the Pacific Northwest. Part 5: Compositae. Univ. Washington Press, Seattle, Wash.

Hyder, D.N., F.S. Sneva, D.O. Chilcote, and W.R. Furtick. 1958. Chemical control of rabbitbrush with emphasis upon simultaneous control of big sagebrush. Weeds 6:289-297.
Jacoby, P.W., C.H. Meadors, and M.A. Foster. 1981. Control of honey mesquite (Prosopis juliflora var. glandulosa) with 3,6-dichloropicolinic acid. Weed Sci. 29:376-378.

Mohan, J.M. 1973. 14 years of rabbitbrush control in central Oregon. J. Range Manage. 26:448-451.

O'Sullivan, P.A., and V.C. Kossatz. 1982. Selective control of Canada thistle in rapeseed with 3,6-dichloropicolinic acid. Can. J. Plant Sci. 62:989-993.

Tueller, P.T., and R.A. Evans. 1969. Control of green rabbitbrush and big sagebrush with 2,4-D and picloram. Weed Sci. 17:233-235.

Whisenant, S.G. 1987. Selective control of mountain big sagebrush (Artemisia tridentata ssp. vaseyana) with clopyralid. Weed Sci. 35:120-123. 